\title{
DETERMINATION OF LEAD, CADMIUM, MERCURY AND ARSENIC HEAVY METALS IN RUMEX VESICARIUS LINN. BY ATOMIC ABSORPTION SPECTROSCOPY METHOD
}

\author{
Miss. S. Ramya, \\ Post graduate student, Department of Pharmaceutical Analysis, Periyar College of \\ Pharmaceutical Sciences, Tiruchirappalli, Tamil Nadu, India. \\ E-Mail. Id: ramyashanthi225@gmail.com \\ Dr. S. Shakila Banu, \\ Associate professor, Department of Pharmaceutical Analysis, Periyar College of \\ Pharmaceutical Sciences, Tiruchirappalli, Tamil Nadu, India. \\ E-Mail.Id: sbpharma84@gmail.com \\ Dr. G. Krishnamoorthy, \\ Vice Principal \& Head, Department of Pharmaceutical Analysis, Periyar College of \\ Pharmaceutical Sciences, Tiruchirappalli, Tamil Nadu, India. \\ E-Mail. Id: vkm292011@hotmail.com \\ Dr. R. Senthamarai,
}

Principal, Department of Pharmacognosy, Periyar College of Pharmaceutical Sciences,

Tiruchirappalli, Tamil Nadu, India.

E-Mail.Id:periyarcps@gmail.com

Mr. M. Sivaganesh,

Post graduate student, Department of Pharmaceutical Analysis, Periyar College of Pharmaceutical Sciences, Tiruchirappalli, Tamil Nadu, India.

E-Mail.Id: sivaganesh2761@gmail.com

Mr. J. Ijaz Ahamed,

Post graduate student, Department of Pharmaceutical Analysis, Periyar College of Pharmaceutical Sciences, Tiruchirappalli, Tamil Nadu, India.

E-Mail.Id: ijazvkr@gmail.com

\section{Corresponding Author:}

Miss. S. Ramya, Post graduate student, Department of Pharmaceutical analysis, Periyar

College of Pharmaceutical Sciences, Tiruchirappalli, Tamil Nadu, India. 


\begin{abstract}
:
Heavy metals are compounds or elements having relatively high density and toxicity at low concentration. Mercury, Cadmium, Arsenic, Chromium, Thallium and Lead are commonly found in plants it can be analysed by using Atomic Absorption Spectroscopy (AAS) method. Heavy metals are of two types. i) Toxic, ii) Essential Lead, Cadmium, Mercury and Arsenic are toxic heavy metals that causes metal poisoning to the patients. The purpose of the study is to determine the heavy metal content in the medicinal plant of Rumex vesicarius Linn. Plant, which has antiemetic, antibacterial, antioxidant, antidiarrheal, anthelmintic, antiinflammatory, antipyretic, hepatoprotective, antimicrobial, antidiabetic, and free radical scavenging properties. The findings of this study were compared with prescribed limits of this metals in the WHO guidelines and the content of all heavy metals was found to be within safe limits. So, the dried powder prepared from this Rumex vesicarius Linn. is safe for further formulation studies in the view of heavy metal toxicity.
\end{abstract}

Keywords:

Atomic Absorption Spectroscopy (AAS), Heavy metals, Rumex vesicarius Linn.

\title{
Introduction: ${ }^{[1,10]}$
}

Herbal medicines have a long history of usage in the treatment, prevention, and management of disease. The vast benefits that herbal medicines provide have led to the majority of the world's population relying on them in some way for various health benefits. According to World Health Organization research, traditional (alternative) medicine is used by 65 to 80 percent of the world's population as their major source of healthcare. The usage of herbal medications, on the other hand, has come under fire due to concerns about long-term toxicity, among other factors.

Rumex vesicarius Linn. is a member of the Rumex genus and Polygonaceae family. Antiemetic, antibacterial, antioxidant, antidiarrheal, anthelmintic, anti-inflammation, antipyretic, antimicrobial, antidiabetic, hepatoprotective, and anticancer are some of the ailments for which it is commonly used as a medicinal herb. West Punjab, the Trans-Indus Hills, Afghanistan, Persia, and North Africa are all home to the plant. Grown in the Bombay presidency's garden areas at any time of year. Rumex vesicarius Linn. is a succulent herb that grows to be $15-30 \mathrm{~cm}$ tall and dichotomously branched. Fleshy, sour alternating leaves that are elliptic-ovate, broadly ovate, whole, acute/obtuse at base, and have a long petiole. Flowers are monoecious and white. Nutlets are the fruits, and the seeds are erect and trigonous. Anthraquinones: emodin and chrysophanol, flavonoids, C-glycosides: vitexin, isovitexin, iso-orientin, rumicine, lapathine, oxalic acid, tannins, mucilage, mineral salts, and vitamin $\mathrm{C}$.

Metal residues are common in herbal plants because they are easily contaminated during their growth, development, and processing. Heavy metals trapped in plants eventually enter the human body after being collected and transformed into medication form, where they may disrupt the normal operations of many organ systems. The World Health Organization has 
underlined the importance of quality assurance for herbal products, including heavy metal testing.

Using the atomic absorption spectrometry method, four elements, $\mathrm{Pb}, \mathrm{Cd}, \mathrm{As}$, and $\mathrm{Hg}$, were quantified in herbal lozenges formulations.

\section{Materials and methods:}

\section{Sample collection and preparation:}

The therapeutic herb was purchased in Tiruchirappalli district. Plant identification was carried out at the National College, Department of Botany in Tiruchirappalli, Tamil Nadu. The samples were washed and air-dried at room temperature for one week in a dust-free environment before being ground into small particles. Prior to examination, the powdered samples were placed in plastic containers and stored in a dry cabinet.

\section{Procedure}

\section{Estimation of Mercury by AAS:}

Prepare mercury standards (NIST traceable) in distilled water to 0.001, 0.002, 0.003, 0.004, $0.005 \& 0.01 \mathrm{mg} / \mathrm{L}$ from a 1000ppm solution. Fill $300 \mathrm{ml}$ BOD bottles with a weighted sample. To each bottle, add $50 \mathrm{~mL}$ of concentrated sulfuric acid and $25 \mathrm{~mL}$ of nitric acid. Allow $15 \mathrm{~mL}$ of a $5 \%$ potassium permanganate solution to stand for at least 15 minutes before using. Heat each $8 \mathrm{~mL}$ of 5 percent potassium persulphate solution in a water bath at $95^{\circ} \mathrm{C}$ for 2 hours. To remove excess permanganate, cool and add $6 \mathrm{ml}$ sodium chloride hydroxylamine sulphate solution. Add $5 \mathrm{~mL}$ of stannous chloride solution after decolorization. Connect the BOD bottle to the aeration device right away to create a closed system. Add $5 \mathrm{~mL}$ of stannous chloride solution after decolorization. Connect the BOD bottle to the aeration device right away to create a closed system. Remove the BOD bottle from the aeration equipment once the reaction is complete, establishing a closed system. Process the blank and standards in the same way as before. Set the AAS according to the task instructions. Aspirate the blank, reference, and sample solutions. Measure the mercury's absorbance at $253.7 \mathrm{~nm}$.

\section{Estimation of Lead by AAS:}

Take a normal flask with a capacity of $100 \mathrm{~mL}$. Prepare lead standards (Nist traceable) in nitric acid (1:499) from $1000 \mathrm{ppm}$ solution to $0.01,0.02,0.04,0.06,0.08 \& 0.1 \mathrm{mg} / 1$. In $100 \mathrm{~mL}$ distilled water, make a blank solution. In a beaker, weigh the sample and digest it with $10 \mathrm{~mL}$ concentrated Nitric acid and $50 \mathrm{~mL}$ hydrochloric acid until the volume is decreased to threequarters. Cool to room temperature and create up to $100 \mathrm{~mL}$ with distilled water. Process the blank in the same way as before. Set the AAS according to the task instructions. Remove the blank, standards, and sample solutions from the aspirator. Calculate the Lead's absorbance.

\section{Estimation of Cadmium by AAS:}

Take a normal flask with a capacity of $100 \mathrm{~mL}$. Prepare Cadmium standards (Nist traceable) in Nitric acid (1:499) from 1000ppm solution to 0.03,0.05,0.07,0.09,0.10 mg/l. In 100mL distilled water, make a blank solution. In a beaker, weigh the sample and digest $50 \mathrm{ml}$ hydrochloric acid until the volume is decreased to three-quarters. Cool to room temperature 
and create up to $100 \mathrm{~mL}$ with distilled water. Process the blank in the same way as before. Set the AAS according to the task instructions. Remove the blank, standards, and sample solutions from the aspirator. Calculate the Cadmium's absorbance.

\section{Estimation of Arsenic by AAS:}

Take a $5 \mathrm{~g}$ sample and place it in a $200 \mathrm{ml}$ beaker. $10 \mathrm{~mL} 2.5 \mathrm{~N}$ sulphuric acid (4.2) and $50 \mathrm{~mL}$ potassium persulphate (5\% potassium chloride) (4.3). Make up to a $50 \mathrm{ml}$ standard flask by boiling until the final volume is reduced to $10 \mathrm{~mL}$. From a 1000ppm solution, prepared arsenic standard solutions of $0.005,0.0075,0.01,0.02,0.04 \& 0.05 \mathrm{mg} / \mathrm{L}$ in distilled water. $50 \mathrm{~mL}$ digest sample in a $200 \mathrm{~mL}$ beaker Wait 30 minutes after adding $5 \mathrm{ml}$ of concentrated hydrochloric acid and $5 \mathrm{~mL}$ sodium iodide solution. $0.5 \mathrm{~mL}$ sodium borohydride solution is added. Assemble the blank and working standards as described above. For AAS operation in VGA, follow the job instructions. Remove the blank, standards, and sample solution from the aspirator. Determine the absorbance of arsenic at $193.7 \mathrm{~nm}$.

\section{Results and discussion:}

The levels of heavy metal present in the Rumex vesicarius Linn. was discussed and the concentration of $\mathrm{As}, \mathrm{Cd}, \mathrm{Hg}$, and $\mathrm{Pb}$ in the Rumex vesicarius Linn. is presented in Table. The heavy metals analysed in the dried herb of Rumex vesicarius Linn. are less than the permissible limits of $0.01 \mathrm{mg} / \mathrm{kg}$.

It is concluded that heavy metals present in Rumex vesicarius Linn. carried using by Atomic Absorption Spectrophotometer were found to be within the standard prescribed limits. The results obtained by this study, concluded that the dry powder of Rumex vesicarius Linn. can be preferred to consume by humankind for various medicinal purposes.

Table 1. Heavy metals in Rumex vesicarius Linn.

\begin{tabular}{|c|c|c|}
\hline S.NO & HEAVY METALS & RESULTS \\
\hline 1 & Lead & BDL(DL:0.01mg/kg) \\
\hline 2 & Cadmium & BDL(DL:0.01mg/kg) \\
\hline 3 & Mercury & BDL(DL:0.01mg/kg) \\
\hline 4 & Arsenic & BDL(DL:0.01mg/kg) \\
\hline
\end{tabular}

*BDL: Below Detection Limit

DL: Detection Limit

\section{Conclusion}

The plant species tested to have safe amounts of the heavy metals and hence may have no harmful impacts are generally linked with heavy metal toxicity on people who use these products for their health needs.

\section{Acknowledgement}


The authors are grateful to the Founder Chairperson Dr. K. Veeramani of Periyar College of Pharmaceutical Sciences, Trichy-21, for extending necessary facilities to carry out this Research.

\section{References}

1. Kofi Annan, Rita A. Dickson, Isaac K. Amponsah, and Isaac K. Nooni The heavy metal contents of some selected medicinal plants sampled from different geographical locations Pharmacognosy Res. 2013 Apr-Jun; 5(2): 103-108

2. SIDANAND V. KAMBHAR. Rumex vesicarius L. (POLYGONACEAE): An Overview. Journal of Global Ecology and Environment 1(1):11-14, 2014

3. Zahra Mousavi, Parisa Ziarati, Mahdieh Esmaeli Dehaghil, Mahnaz Qomi Heavy Metals (Lead and Cadmium) in some Medicinal Herbal Products in Iranian Market IJT 2014; 1004 1010

4. Kumar Sukender, Singh Jaspreet, Das Sneha and Garg Munish AAS Estimation of Heavy Metals and Trace elements in Indian Herbal Cosmetic Preparations Research Journal of Chemical Sciences Vol. 2(3), 46-51, March (2012)

5. Kofi Annan, Asanate Issac Kojo, Asare Cindy, Asare-Nkanah Samuel and Bayor Marcel Tunkumgnen Profile of heavy metals in some medicinal plants from Ghana commonly used as components of herbal formulations pharmacognosy research 2010 Jan-Feb; 2(1): 41-44.

6. Muhammad Saeed*, Naveed Muhammad, Haroon Khan and Zakiullah Assessment of Heavy Metal Content of Branded Pakistani Herbal Products Tropical Journal of Pharmaceutical Research August 2011; 10 (4): 499-506.

7. Marian Asantewah Nkansah, Samuel Takyi Hayford, Lawrence Sheringham Borquaye \& James Hawkins Ephraim | (2016) Heavy metal contents of some medicinal herbs from Kumasi, Ghana, Cogent Environmental Science, 2:1, 1234660, DOI: 10.1080/23311843.2016.1234660 8. Heavy Metal Induced Gene Expression in Plants. International Journal of Scientific and Technological Research. 2019.

9. Tangahu B, Sheikh Abdullah S, Basri H, Idris M, Anuar N, Mukhlisin M. A Review on Heavy Metals (As, Pb, and Hg) Uptake by Plants through Phytoremediation. 2022.

10. Maehasi H, Yamaguchi Y, Tsutsumi S. Arsenic and copper excretion after treatment of arsenic poisoning in rats with heavy metal antagonists. Toxicology Letters. 1983; 18:116. 